Gonchar M.O., Ishchenko T.B., Orlova N.V., Muratov G.*, Kolibaeva T.*, Khmara N.*, Podvalnaya N*. \title{
CONDITION AFTER HEMOLYTIC-UREMIC SYNDROME IN A CHILD WITH 3RD STAGE CHRONIC KIDNEY DISEASE (case report)
}

Kharkiv National Medical University, Ukraine Kharkiv Regional Children's Clinical Hospital *

\begin{abstract}
Currently, hemolytic-uremic syndrome is one of the frequent causes of acute kidney failure in children, so the timeliness of diagnosis and treatment determines the outcome of the disease. In the given clinical case, a set of certain factors that lead to an unfavorable outcome of the disease and the progression of chronic renal failure are presented. Clinical case of a 14-year-old child K., who was admitted to the nephrology department of the Regional Children's Clinical Hospital with the diagnosis: 3rd stage CKD, subcompensated stage of chronic renal failure and condition after hemolytic-uremic syndrome.
\end{abstract}

KeyWords: hemolytic-uremic syndrome in children, chronic kidney disease.

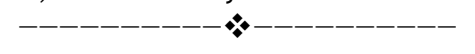

Hemolytic-uremic syndrome is a polyetiological disease secondary to other diseases and usually leading to severe damage to the endothelium of the vessels of the target organs. For reasons of origin, it can be divided into infectious and non-infectious forms. Early identification and the initiation of the best maintenance care with a microbiological contribution to pathogen detection lead to a favorable outcome in most patients [1]. Hemolytic-uremic syndrome occurs throughout the world. The annual incidence in children under five years is $2-3$ cases per 100,000 children. According to both foreign and Ukrainian clinicians, this syndrome is most typical for infancy and early age (from 6 months to 4 years). In addition, hemolytic-uremic syndrome is one of the frequent causes of disability of patients with the deveelopment of chronic renal failure [2]. The incidence of hemolytic-uremic syndrome and its complications according to the Regional Children's Clinical Hospital from 2011 to 2016 recorded 5 cases of hemolyticuremic syndrome.

\section{Corresponding Author:}

Tatiana Ishenko, MD, PhD, Associate Professor, Department of Pediatrics 1 and Neonatology, Kharkiv National Medical University, Ukraine. E-mail: 7tanyatb7@gmail.com
A 14-year-old girl K. diagnosed with 3rd stage chronic kidney disease, subcompensated stage of chronic renal failure, congenital anomaly of the urinary system (horseshoe kidney), condition after hemolytic-uremic syndrome (2003), secondary chronic pyelonephritis, remission period and polycystic disease.

Past history: 3rd pregnancy child, 2nd childbirth, term birth, birth weight $2800 \mathrm{~g}$, height $50 \mathrm{~cm}$, Apgar score: 8-9 points. She grew up and developed according to her age. She often has acute respiratory-viral diseases. She was administered Proteflazidum for Epstein-Barr virus infection (Epstein-Barr virus DNA in saliva +++) from 12.04.09 to 12.07.09. In October 2009 she was treated for anemia. Bilateral sinusitis in September 2012. She did not have children's infections. Heredity in nephropathy is not compromised.

At the age of 7 months, she developed hemolyticuremic syndrome, secondary to acute intestinal infection and congenital anomaly of the kidneys (horseshoe kidney). These changes were confirmed by radioisotope renography and renoscintigraphy. The course of hemolytic-uremic syndrome was complicated by secondary chronic pyelonephritis, secondary glomerulonephritis with 1st stage chronic renal insufficiency, long anuric stage during the onset of 
the disease (anuria for more than 10 days), which was managed by 6 sessions of peritoneal dialysis. She was discharged with improvement for a follow-up observation of the nephrologist. Thus far (within the last 5 years), relapses of pyelonephritis were observed every year, for which the child received appropriate therapy. Since September 2012, recurrence of urinary tract infection has not been reported and the child continues to be observed for 2 nd stage chronic kidney disease. She receives antihypertensive, renoprotective, and anti-relapse therapy with uroseptics. In 2016 the child was diagnosed with polycystic kidney disease, which is one of the factors contributing to the progression of chronic kidney failure.

Criteria for the diagnosis of hemolytic-uremic syndrome [3]:

- microangiopathic hemolytic anemia

- kidney failure

- thrombocytopenia

Pathophysiological aspects of hemolytic-uremic syndrome development:

Glomerular thrombotic microangiopathy, a thickening of the wall of the renal vessels with edema of the endothelium and accumulation of proteins in their subendothelial layer is one of the main factors triggering kidney damage in hemolytic-uremic syndrome.

Moreover, pathophysiological mechanisms include the development of glomerular ischemia, which, in combination with thrombosis, leads to multifocal or diffuse necrosis of the cortex, followed by their occlusion with fibrin clots [4].

\section{Classification [5]:}

Infectious:

- verotoxin-producing E. coli

- Shigella dysenteriae

- microorganisms secreting neuraminidase (Str. Pneumoniae, etc.)

- HIV infection, etc.

Non-infectious:

- Idiopathic hemolytic-uremic syndrome

- Hereditary hemolytic-uremic syndrome (autosomal recessive, autosomal dominant)
- Drug hemolytic uremic syndrome (cyclosporin A, mitomycin C, bleomycin, duanorubicin, cytosinearabinoside, cyclophosphamide, carboplatinum, doxorubicin, chlorozotocin, oral contraceptives, etc.);

- Hemolytic-uremic syndrome associated with pregnancy;

- Hemolytic-uremic syndrome associated with organ transplantation;

- Hemolytic-uremic syndrome associated with systemic lupus erythematosus;

- Hemolytic-uremic syndrome associated with tumors;

- Hemolytic-uremic syndrome, associated with scleroderma;

- Hemolytic-uremic syndrome, associated with malignant hypertension;

- Hemolytic-uremic syndrome, layered on glomerulonephritis.

Clinical and laboratory criteria of diagnosis [6]:

- Intoxication syndrome

- Anemic syndrome

- Hemorrhagic syndrome

- Kidney syndrome

\section{Prognosis $[7,8]$ :}

- Polyuric stage of acute renal failure (1-1.5 months) is a favorable outcome of the acute stage of hemolytic-uremic syndrome.

- Causes of deaths: central nervous system involvement, cardiopulmonary and multi-organ failure.

- The level of mortality ranges from 5 to $15 \%$, in underdeveloped countries to $70 \%$ depending on the adequacy and timeliness of medical care, .

- The analysis of follow-up data shows that up to $85 \%$ of patients restore renal function.

- In 5-7 years after hemolytic-uremic syndrome 5\% patients develop chronic renal failure, in 15 years more than $25 \%$ of patients suffer from chronic renal failure development. Unfavorable prognostic signs are: early anuria and its duration more than 
2 weeks, progressive involvement of the central nervous system, urinary tract infections, microthrombi in more than $60 \%$ glomeruli, leukocytosis more than $20 \times 109 /$, atypical form of hemolytic uremic syndrome, age from 6 months and up to 4 years, as well as urinary system abnormalities /

\section{Follow-up [9]:}

- control of blood pressure;

- control of kidney function (serum creatinine, urine analysis (proteinuria level).

In a number of cases, chronic renal failure after hemolytic-uremic syndrome develops after a certain period of well-being. Progressive kidney damage can be suggested by persistence or development of proteinuria after a certain period after recovery, accompanied with or without arterial hypertension.

The closest or long-term prognosis of the disease is directly related to the severity of the acute period. The most reliable criterion is undoubtedly the duration of the oligoanuric period, which determines the formation of pathomorphological changes in the kidneys and the incidence of chronic renal failure [10].

\section{CONCLUSIONS}

Thus, according to the analyzed data, unfavorable outcome of hemolytic-uremic syndrome with the development and progression of chronic renal failure in our patient were determined by the following reasons: prolonged oligoanuric stage during the onset of the HUS, the early age of the child, urinary system abnormalities, and the urinary tract infection.

\section{CONFLICT OF INTERESTS}

There is no conflict of interests.

\section{REFERENCES}

1. Kavanagh, D., Raman, Sh., Et Neil S. Sheerin (2014). Management of hemolytic uremic syndrome. F1000Prime Rep., 6, 119. doi: 10.12703/P6-119

2. Boyer, O., Niaudet, P. (2011). Hemolytic Uremic
Syndrome: New Developments in Pathogenesis and Treatment. International Journal of Nephrology, 10. Available at: http: //dx.doi.org/10.4061/2011/908407

3. Krasnova E. I., Gajnc O. V., Loskutova S. A. (2009). Gemolitiko-uremicheskij sindrom kak oslozhnenie ostroj kishechnoj infekcii u detej. [Hemolytic-uremic syndrome as a complication of acute intestinal infection in children]. Medicinskij nauchno-prakticheskij portal «Lechashhij vrach». Available at: https://www.lvrach.ru/2010/10/15435054/

4. Cygin A.N., Vashurina T.V., Margieva T.V., Anan'in P.V. (2015). Federal'nye klinicheskie rekomendacii po okazaniju pomoshhi detjam s gemolitiko-uremicheskim sindromom. Klinicheskie rekomendacii. [Federal clinical guidelines for assisting children with hemolytic-uremic syndrome. Clinical recommendations]. Pediatricheskaja farmakologija, 12 (4), pp. 447-455. doi: 10.15690/pf.v12i4.1427

5. Mironov L.L., Kanus I.I. (2003). Gemolitikouremicheskij sindrom: jetiologija, jepidemiologija, patogenez. [Hemolytic-uremic syndrome: etiology, epidemiology, pathogenesis]. Zhurnal «Medicinskie novosti», no 10. Available at: http: / /www.mednovosti.by/journal.aspx?article=2445

6. Salvadori, M., Bertoni, E. (2013). Update on hemolytic uremic syndrome: Diagnostic and therapeutic recommendations. World J Nephrol., 2 (3), 56-76. doi: 10.5527/wjn.v2.i3.56

7. Jagabandhu Ghosh, Dipankar Gupta Et Nibedita Chattopadhyay (2016). Hemolytic Uremic Syndrome. J Nephrol Ther, 6, 239.

8. Nur Canpolat (2015). Hemolytic uremic syndrome. Turk Pediatri Ars., 50(2), 73-82.

9. Adrovic, A., Canpolat, N., Caliskan, S. Et Sever L. (2016). Cobalamin C defect-hemolytic uremic syndrome caused by new mutation in MMACHC. Pediatr Int., 58(8), 763-5.

10. Makarova T. P., Mrasova V. K., Shakirov I. D. (2006). Gemolitiko-uremicheskij sindrom u detej. [Hemolytic-uremic syndrome in children]. Pediatrija, 5 (19), pp. 18-19.

Received: $\quad$ 08-Aug. - 2017

Accepted: $\quad$ 21-Sep. - 2017 